\title{
Instruments and Criteria for Research and Analysis of the Internet Visibility of Bulgarian Judicial Institutions WEB-Space*
}

\author{
Nayden Valkov Nenkov \\ Faculty of Mathematics and Informatics \\ University of Shumen "Episkop Konstantin Preslavsky" \\ Shumen, Bulgaria
}

\author{
Mariana Mateeva Petrova \\ Faculty of Mathematics and Informatics \\ St. Cyril and St. Methodius University of Veliko Turnovo, \\ Bulgaria
}

\begin{abstract}
Justice has been under discussion at European level since 2007. The article describes some tools and displays objective criteria for evaluating the WEB-pages of judicial institutions in Bulgaria. A methodology is offered in order to improve the organization and functioning of the judicial institutions. It is used to conduct experimental tests for analysis and assessment of the main characteristics of the Bulgaria courts' WEB-sites. The results provide grounds for findings and recommendations leading to improved communication and the presence of these institutions in the WEB.
\end{abstract}

Keywords-judicial institution; WEB-page; SEO (search engine optimization); evaluation criteria; court

\section{INTRODUCTION}

The evaluation of the judicial WEB-sites is an important task in the context of the radical reform made in this area. This evaluation must be consistent with the overall vision and the project to build an e-government with the EC requirements and the standards which exist for e-administration and e-services to the population in Bulgaria [1, 3].

On 18 December 2008 The European Parliament adopted a Resolution on e-Justice, on 22 October 2013 it adopted a Resolution on e-Justice calling for the use of electronic applications, the electronic provision of documents, the use of videoconferencing and the interconnection of judicial and administrative registers to be increased, in order to further reduce the cost of judicial and out-of-court proceedings $[4,7]$.

The existing European roadmap covers the objectives for the European projects in the field of e-Justice up until 2013. Some of the existing projects will only bear visible results after that period since the development of European-wide IT projects of preliminary groundwork.

Along with the many administrative, organizational, social and aesthetic requirements $[6,10,11]$, there are also technical ones. They have been largely set in a number of tools to evaluate the WEB-content of the sites. The existence of a website is not enough. The questions, related to the Internet visibility of the web-site, are also of importance.

The official list of all courts is published on the website of the Supreme Judicial Council. Links to the websites of all

* The research is financed by project № 08-306/12.03.2015, Research on intelligent methods and applications of simulators for neural networks and optimal methods of learning process of University of Shumen courts are available on the website of the Supreme Cassation Court in the section "Useful links".

The first stage of the study was implemented in January 2013 between 07 and 14. The survey covered all courts by type: 7 Appellate courts; 28 District courts; 113 Regional courts; 5 Military courts; 28 Administrative courts and the Specialized Criminal Court $[5,6]$.

\section{EXPOSITION}

The subject of the study is to improve the presence of judicial institutions on the WEB in order to provide the necessary services citizens and the transparency of their activities. Part of the reviewed tools is used for SEOoptimization, but it is not the focus here and goes beyond the scope of issues discussed.

Before evaluating a WEB-site of an administrative unit of the judicial system, we should establish the criteria and their weight in the overall assessment. The analyzed sources [2, 3, 8, 12] offer various criteria that show different quantitative and qualitative characteristics of the sites.

There are numerous tools that facilitate both WEBdesigners and experts in the creation of this type of software, as well as the experts and managers responsible for them.

Therefore are need to validate the WEB-sites and their codes according to the standard of WWW $[2,12]$ and evaluate to various characteristics such as site rating, and more.

In order to meet the set requirements and criteria for accessibility level, set by the European Commission about the websites of public administration, and also to meet the requirements of the current Internet technologies, the Web-sites of the institutions must adhere to the standards of WCAG 2.0 and the level of compliance "Double-A". Web sites of the institutions should cover the accessibility level Double-A according to the latest standards of the World Wide Web Consortium - Web Content Accessibility Guidelines 2.0 (WCAG 2.0) by the using best practices and techniques.

\section{TOOLS}

Here are discussed some of the most commonly used tools in practice, which give an idea of the types of tests and WEBsites' inspection procedures. 


\section{A. The validator of W3C - Markup Validation Service}

Markup Validation Service http://validator.w3.org/ - checks the validity of WEB-documents by using the scripting languages: HTML, XHTML, SMIL, MathML and checking whether the site carries out the ISO / IEC standard 15445: 2000 Information technology - Document description and processing languages - HyperText Markup Language (HTML) [2, 11]. For the validation a specific content such as RSS / Atom feeds or CSS styles, MobileOK content, or to find broken links is which there are other varieties of that validator are used for.

\section{B. SEO-optimization Tool}

"SEO-optimization Tool" [11, 12] also deserves attention, but only some of its functions can be used for free: check site ranking, loading speed and coding URL, while others like the automatic SEO analysis and analysis of external links are to be paid for.

\section{Open Site Explorer Tool}

The tool „Open Site Explorer“(fig.1) is powerful and multifunctional [9], gives an option for complex optimization. It allows to evaluate the rating of the domain, the WEB-site, the link metrics, the social metrics (not available in trial version), and the quantitative assessment of the sanctioned spam and inbound links to the site.

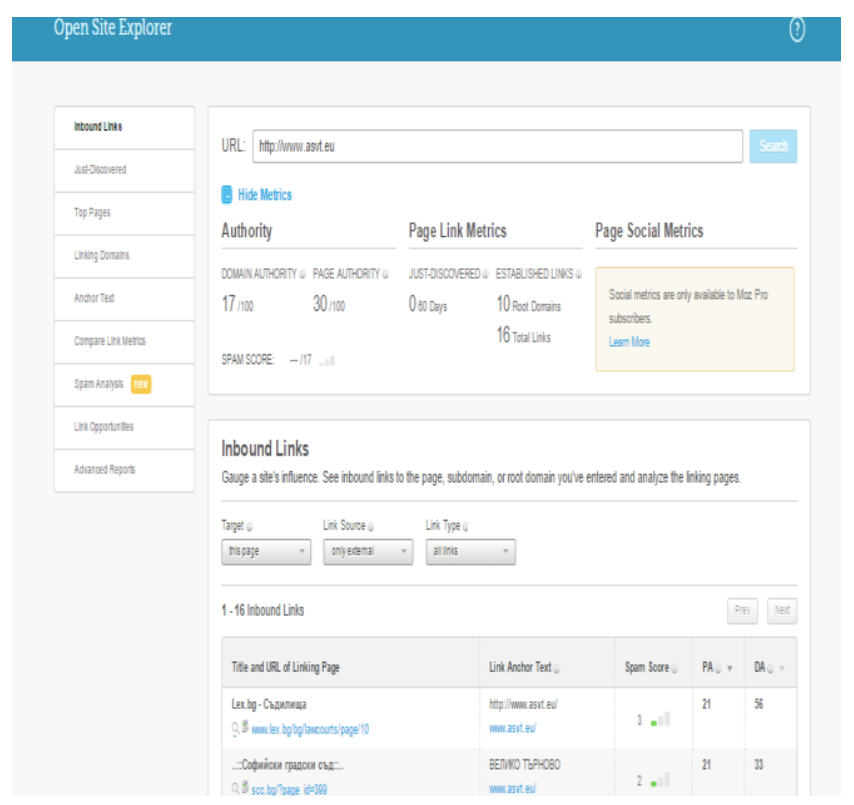

Fig. 1. Tool for complex SEO-optimization and testing of WEB-sites

\section{PINGDOM TOOLS}

PINGDOM TOOLS provide some excellent possibilities for precise monitoring of WEB-sites (Fig. 2). Pingdom performs a global monitoring of WEB-sites and WEBapplications [8]. It has the following functions:

Uptime MONITORING - tests and verifies the presence of sites in the WEB-space every minute automatically from over 60 selected global locations

- REAL USER MONITORING - accumulates and stores valuable performance data of the WEB-site, based on actual visits from users in order to improve its performance.

- TRANSACTION MONITORING - shows if important interactions and operations with the site such as registration, search or downloading files are slow or crashed.

- DevOps - integrates with other mostly cloud applications to correlate site data with given indicators in real-time, in order to improve productivity.

- RELIABLE - allows any problems encountered to be checked by a second opinion to achieve filtering of false alarms through this double check.

- ROOT CAUSE ANALYSIS - determines the causes of errors and interruptions in the WEB-site or server to solve problems and prevent their reoccurrence.

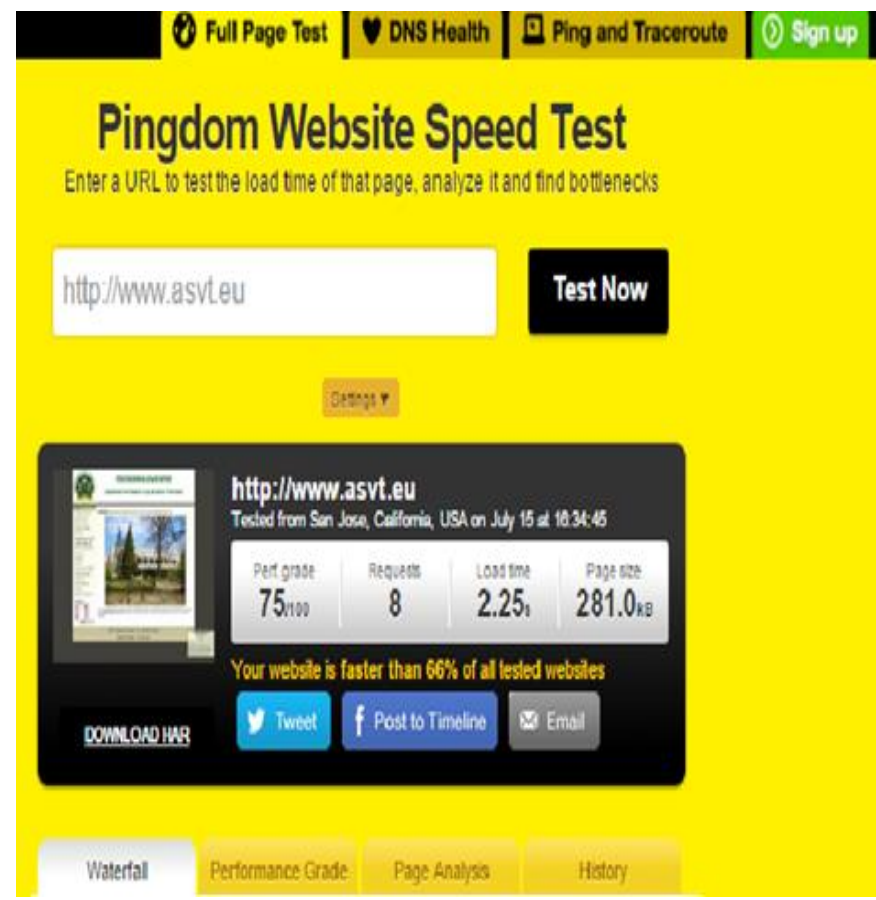

Fig. 2. Pingdom tool for monitoring WEB-sites and WEB-applications

\section{CRITERIA}

The evaluation $\boldsymbol{E}$ of WEB-pages from sites of the judicial system can be defined by the multitude:

$$
\boldsymbol{E}=\left\{\boldsymbol{K}_{i j}, \boldsymbol{O}_{j}, \boldsymbol{S}_{j}\right\}
$$

where $K_{i j}=V_{j k} ; \quad i=1, . ., m ; j=1, . ., n ; k=1, \ldots, b ; V_{j k}-$ numeric evaluations of the criteria, $\boldsymbol{m}$ - number of evaluation criteria (received by the tools for evaluating WEB-sites),

$\boldsymbol{n}$ - number of evaluated judicial institutions, $\boldsymbol{b}$ - extreme values of the scale of the evaluated values, complex criteria $\boldsymbol{O}_{\boldsymbol{j}}$ and $S_{j}$ have values in the interval + or $-[0, \ldots 1]$.

The calculation of the criterion for evaluating the judicial WEB-sites is one of the most important stages in the process. You can define the following rules for calculation. 
1) The value of the first criteria $K 1$ is derived from the check with the validator described above (fig. 1) and is defined:

- If the site cannot be validated $\mathbf{K}_{\mathbf{1}}$ is not evaluated and is marked with NO in Table 1, part of which is shown below;

- If it is validated with errors, the derived value $\mathbf{V}_{\mathbf{1}}$ is recorded in the same table and $\mathbf{K}_{\mathbf{1}}=\mathbf{V}_{\mathbf{1}}$ for the evaluated object;

- If there are no errors $\mathbf{V}_{\mathbf{1}}=\mathbf{0}$ and so $\boldsymbol{K}_{\mathbf{1}}=\mathbf{0}$.

2) The criterion reflecting a site's ranking in productivity $\boldsymbol{K}_{2}$ is defined like that:

- If $\mathbf{K}_{\mathbf{2}}=\mathbf{0}$ then $\boldsymbol{K}_{\mathbf{2}}$ is not evaluated and we do not record anything in Table 1 (leave an empty cell);

- Else the derived value $\mathbf{V}_{2}$ is filled in the same table and $\mathbf{K}_{\mathbf{2}}=\mathbf{V}_{\mathbf{2}}$ for the evaluated object.

The site is ranked, taking into account the results of tests passed until its conducting.

3) The number of requests necessary for loading the site $\boldsymbol{V}_{3}$ define the criteria $\boldsymbol{K}_{3}$

- If $\mathbf{K}_{\mathbf{3}}=\mathbf{0}$ then $\mathbf{K}_{\mathbf{3}}$ is not evaluated and we do not record anything in Table 1 (leave an empty cell)

- Else the derived value $\mathbf{V}_{\mathbf{3}}$ is filled in the same table and $\mathbf{K}_{\mathbf{3}}=\mathbf{V}_{\mathbf{3}}$ for the evaluated object.

This value describes the number of required elements of the site that need to be loaded for its proper operation.

4) Site loading time $-\boldsymbol{V}_{\mathbf{4}}$ defines the criterion $\boldsymbol{K}_{\mathbf{4}}$

It is defined in the following way:

- If $\mathbf{K}_{\mathbf{4}}=\mathbf{0}$ then $\mathbf{K}_{\mathbf{4}}$ is not evaluated and we do not record anything in Table 1 (leave an empty cell)

- Else the derived value $\mathbf{V}_{\mathbf{4}}$ is filled in the same table and $\mathbf{K}_{\mathbf{4}}=\mathbf{V}_{\mathbf{4}}$ for the evaluated object in seconds.

The largest and most authoritative company in this business GOOGLE ranks well a site only if it loads quickly. If the site is slow, it cannot optimize well.

The rating is good at loading speed from 0 to $1 \mathrm{sec}, 2$ to 3 seconds is average and the owners should work to improve it, and more than 4 seconds means that the owners must definitely optimize it.

5) Site total size - $\boldsymbol{K}_{5}$

This criteria is defined like that:

- If $\mathbf{K}_{\mathbf{5}}=\mathbf{0}$ then $\boldsymbol{K}_{\mathbf{5}}$ is not evaluated and we do not record anything in Table 1 (leave an empty cell)

- Else the derived value $\mathbf{V}_{5}$ is filled in the same table and $\mathbf{K}_{\mathbf{5}}=\mathbf{V}_{\mathbf{5}}$ for the evaluated object in seconds.

The size of the WEB-site should be optimal, depending on its purpose. The table is filled in with values in kilobytes $(\mathrm{Kb})$. It is preferable the site to have a minimum size.
The results of the experiment conducted in May 2015 on 182 courts in Bulgaria are shown in Table 1.

TABLE I. PART OF THE EVALUATIONS OF THE JUDICIARY WEB-SiteS IN BULGARIA

\begin{tabular}{|c|c|c|c|c|c|c|c|}
\hline № & Name & $\begin{array}{l}\text { WEB- } \\
\text { site } \\
2015\end{array}$ & $\begin{array}{l}\text { Valid. of } \\
\text { WEB- } \\
\text { sites } \\
\text { (errors) } \\
\text { V }_{1}\end{array}$ & $\begin{array}{l}\text { Site } \\
\text { rank by } \\
\text { prod. } \\
\text { (out of } \\
100) \\
V_{2} \\
\end{array}$ & $\begin{array}{l}\text { Num. } \\
\text { reques } \\
\text { ts } \\
V_{3}\end{array}$ & $\begin{array}{l}\text { Load } \\
\text { time } \\
(s) \\
V_{4}\end{array}$ & $\begin{array}{l}\text { Site } \\
\text { size } \\
(\mathbf{K b}) \mathrm{V} \\
5\end{array}$ \\
\hline 1 & 2 & 4 & 5 & 6 & 7 & 8 & 9 \\
\hline 1 & $\begin{array}{l}\text { Burgas } \\
\text { Court of } \\
\text { Appeal }\end{array}$ & $\begin{array}{l}\text { www. } \\
\text { bgbas. } \\
\text { org }\end{array}$ & 21 & 87 & 29 & 0,829 & 131,4 \\
\hline 2 & $\begin{array}{l}\text { Varna } \\
\text { Court of } \\
\text { Appeal }\end{array}$ & $\begin{array}{l}\text { www. } \\
\text { appeal } \\
\text { court- } \\
\text { varna. } \\
\text { org }\end{array}$ & 1 & 85 & 20 & 1,39 & 250,5 \\
\hline 5 & $\begin{array}{l}\text { Sofia } \\
\text { Court of } \\
\text { Appeal }\end{array}$ & $\begin{array}{l}\underline{\text { acs.co }} \\
\underline{\text { urt- }} \\
\underline{\text { bg.org }}\end{array}$ & no & & & & \\
\hline 14 & $\begin{array}{l}\text { Adminis } \\
\text { trative } \\
\text { Court } \\
\text { Burgas }\end{array}$ & $\begin{array}{l}\underline{\text { http:// }} \\
\text { www. } \\
\text { admco } \\
\text { urt- } \\
\text { bs.org }\end{array}$ & 19 & 82 & 29 & 1,97 & 250,5 \\
\hline & $\ldots$ & $\ldots$ & $\ldots$ & $\ldots$ & $\ldots$ & $\ldots$ & $\ldots$ \\
\hline 182 & $\begin{array}{l}\text { Regional } \\
\text { Court - } \\
\text { Yambol }\end{array}$ & $\begin{array}{l}\text { http:// } \\
\text { yambo } \\
\text { l.court } \\
\text { - } \\
\text { bg.org }\end{array}$ & no & & & & \\
\hline
\end{tabular}

In order for the WEB-site to be evaluated, it is necessary to consider the impact of all criteria on its functionality. This is accomplished by making the following steps, which are used in the methodology [5, 6]:

\section{A. Remove the results of experimental data beyond borders}

It is believed they are due to errors in the reporting of the primary data obtained or other non-specific events during the experiment.

For each criteria, the mean square deviation is calculated and it is determined whether there are values out of range $(-3 \sigma$, $+3 \sigma)$. If there are such values they are brought to value of the nearest border. WEB-sites that cannot be validated are excluded from calculations of further steps!

B. Normalization of criteria for evaluated objects - Web-sites of the courts

$$
K_{i j}=\frac{v_{i j}-v_{j a v g}}{\sigma} * 100
$$

Where $K_{i j}-i$ criteria for the $j$ site $i=1, \ldots, m ; j=1, \ldots . n$.

Performed through transformation that takes into account the averages and deviations from them.

The obtained results are Table 2 where each of the rows contains a vector with values of the criteria $K_{1}$ to $K_{5}$ (column 2 to 6) for a WEB-site. The values which are negative are below average importance, and those with a positive sign are above average importance. 
TABLE II. VALUES OF CRITERIA AND RANKING OF THE SITES OF THE JUDICIARY

\begin{tabular}{|c|c|c|c|c|c|c|c|c|}
\hline \begin{tabular}{|l} 
№ \\
\end{tabular} & $\mathbf{K}_{1}$ & $\mathbf{K}_{2}$ & $\mathbf{K}_{3}$ & $\mathbf{K}_{4}$ & $\mathbf{K}_{5}$ & $\mathbf{O}_{\mathrm{ij}}$ & $S_{i j}$ & R. \\
\hline 1. & 2. & 3. & 4. & 5. & 6. & 7. & 8. & 9. \\
\hline $\begin{array}{l}16 \\
0\end{array}$ & $\begin{array}{l}- \\
0,000963 \\
726\end{array}$ & $\begin{array}{l}- \\
0,36354 \\
88\end{array}$ & $\begin{array}{l}- \\
0,029 \\
33\end{array}$ & $\begin{array}{l}- \\
0,001 \\
28\end{array}$ & \begin{tabular}{|l}
- \\
0,001 \\
02
\end{tabular} & $\begin{array}{l}0,760 \\
647\end{array}$ & $\begin{array}{l}0,1521 \\
2946\end{array}$ & 1 \\
\hline 12 & $\begin{array}{l}0,014442 \\
872\end{array}$ & $\begin{array}{l}0,36061 \\
2219\end{array}$ & $\begin{array}{l}- \\
0,017 \\
98 \\
\end{array}$ & $\begin{array}{l}- \\
0,001 \\
42\end{array}$ & \begin{tabular}{|l}
- \\
0,000 \\
86 \\
\end{tabular} & $\begin{array}{l}0,729 \\
849\end{array}$ & $\begin{array}{l}0,1459 \\
6982\end{array}$ & 2 \\
\hline 74 & $\begin{array}{l}0,005407 \\
937\end{array}$ & $\begin{array}{l}0,36061 \\
2219\end{array}$ & $\begin{array}{l}0,018 \\
91\end{array}$ & $\begin{array}{l}0,001 \\
49\end{array}$ & $\begin{array}{l}0,000 \\
76 \\
\end{array}$ & $\begin{array}{l}0,727 \\
07\end{array}$ & $\begin{array}{l}0,1454 \\
1391\end{array}$ & 3 \\
\hline 7 & $\begin{array}{l}0,007924 \\
696\end{array}$ & $\begin{array}{l}0,36061 \\
2219\end{array}$ & $\begin{array}{l}- \\
0,037 \\
84\end{array}$ & $\begin{array}{l}- \\
0,000 \\
82\end{array}$ & $\begin{array}{l}- \\
0,001 \\
2\end{array}$ & $\begin{array}{l}0,697 \\
213\end{array}$ & $\begin{array}{l}0,1394 \\
4259\end{array}$ & 4 \\
\hline 27 & $\begin{array}{l}- \\
0,001852 \\
569\end{array}$ & $\begin{array}{l}- \\
0,32331 \\
7632\end{array}$ & $\begin{array}{l}- \\
0,043 \\
51\end{array}$ & $\begin{array}{l}- \\
0,001 \\
38\end{array}$ & $\begin{array}{l}- \\
0,000 \\
76 \\
\end{array}$ & $\begin{array}{l}0,695 \\
997\end{array}$ & $\begin{array}{l}0,1391 \\
9947\end{array}$ & 5 \\
\hline $\begin{array}{l}14 \\
4\end{array}$ & $\begin{array}{l}- \\
0,002148 \\
849\end{array}$ & $\begin{array}{l}0,36061 \\
2219\end{array}$ & $-0,035$ & $\begin{array}{l}- \\
0,001 \\
55\end{array}$ & $\begin{array}{l}0,000 \\
831\end{array}$ & $\begin{array}{l}0,681 \\
209\end{array}$ & $\begin{array}{l}0,1362 \\
4183\end{array}$ & 6 \\
\hline 57 & $\begin{array}{l}- \\
0,004222 \\
814\end{array}$ & $\begin{array}{l}0,36061 \\
2219\end{array}$ & $\begin{array}{l}- \\
0,029 \\
33 \\
\end{array}$ & $\begin{array}{l}- \\
0,001 \\
45 \\
\end{array}$ & \begin{tabular}{|l|}
- \\
0,000 \\
91 \\
\end{tabular} & $\begin{array}{l}0,681 \\
092\end{array}$ & $\begin{array}{l}0,1362 \\
1841\end{array}$ & 7 \\
\hline$\ldots$ & $\ldots$ & $\ldots$ & $\ldots$ & $\ldots$ & $\ldots$ & $\ldots$ & $\ldots$ & $\ldots$ \\
\hline $\begin{array}{l}10 \\
4\end{array}$ & 0,003184 & $\begin{array}{l}- \\
0,00146 \\
8\end{array}$ & $\begin{array}{l}- \\
0,000 \\
953\end{array}$ & $\begin{array}{l}- \\
0,000 \\
894\end{array}$ & \begin{tabular}{|l|}
- \\
0,000 \\
346
\end{tabular} & $\begin{array}{l}0,001 \\
239\end{array}$ & $\begin{array}{l}0,0002 \\
48\end{array}$ & 137 \\
\hline
\end{tabular}

C. The integrated evaluation of each site is determined by the expression:

$$
O_{i}=\sum_{J=1}^{n} w_{j} v_{i j}
$$

where $\mathrm{i}=1, \ldots \mathrm{m}, \quad \mathrm{j}=1, \ldots, \mathrm{n}, \quad w_{j}$-weight coefficient indicating the importance of each criterion, $v_{i j}$ - numeric value of criteria $\mathrm{j}$ for site $\mathrm{i}$.

This evaluation $O_{i j}$ weighs the different criteria in the final evaluation. In this case the weight of the first and the second criteria is $\boldsymbol{w}_{1,2}=2$, which means that they are basic and have a two times greater effect than the other three which are of weight $\boldsymbol{w}_{3,4,5}=1$. They are shown in column 7 of Table 2 .

\section{Complex evaluation of sites}

$$
S_{i}=\frac{\sum_{j=1}^{n} o_{i j}}{n}
$$

where $\mathrm{i}=1, \ldots \mathrm{m}, \mathrm{m}$-number of the evaluated sites (does not include non-validating sites), $\mathrm{j}=1, \ldots, \mathrm{n}, \mathrm{n}=5, \mathrm{O}_{i j}$ - integrated evaluation $\mathrm{j}$ for site $\mathrm{i}$.

The complex evaluation of WEB-sites of the judicial system is calculated as the average of the evaluation of other criteria and their weighted influence. Thus the qualities of the development and functioning of the sites are considered. The results are in column 9 of Table 2.

\section{DISCUSSION}

The results show that $45(24.73 \%)$ of the sites cannot be validated and are excluded from the evaluation. This leads to a violation of the standard and the urgent need to take action to resolve the issue.

The remaining 137 sites are validated with different number of errors in the code, adversely affecting their quality. There are 16 sites in which no errors were made and complied with standard WWW $[2,12]$.

The integrated $\mathrm{O}_{\mathrm{i}}$ and the complex evaluation $\mathrm{S}_{\mathrm{i}}$ are illustrated in Fig. 3.

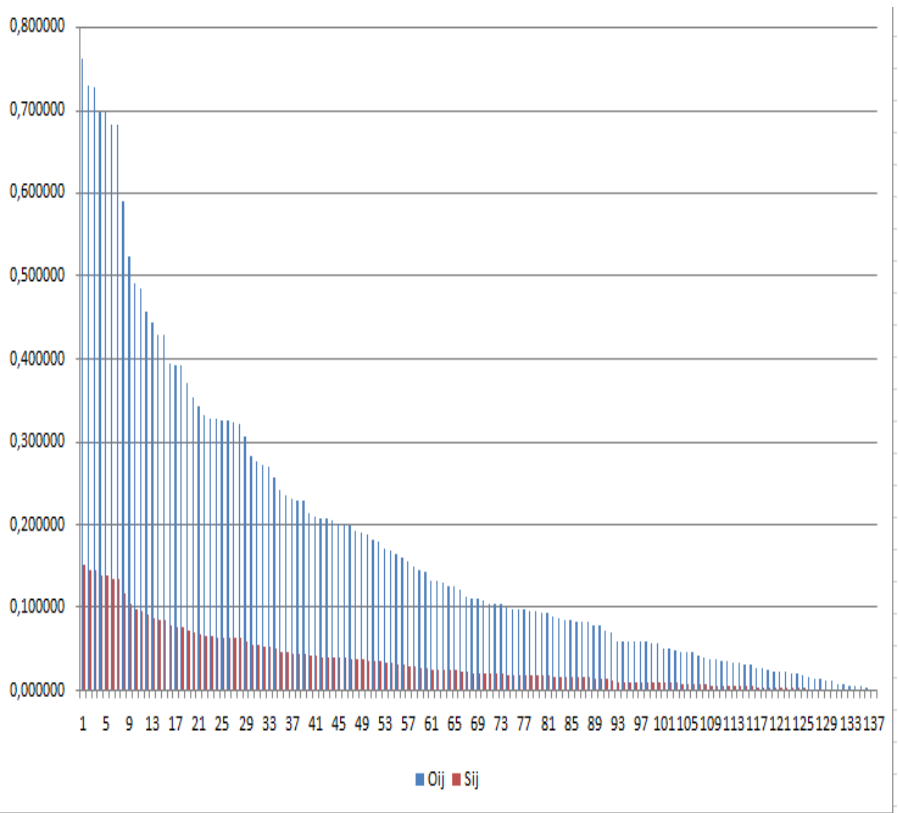

Fig. 3. Integrated and comprehensive assessment of websites

\section{CONCLUSION}

The existing WEB-pages of the courts are evaluated by appropriately selected criteria, tools and methodology. The proposed conclusions and recommendations were obtained after analyzing the experimentally determined values of several criteria. They cover the important features of this type of communication and their visual expression in the WEB-space.

A large number (45) of the pages of judicial institutions are not validated and cannot be evaluated. They need to be adjusted and adapted to the standard for validating the content.

The remaining (137) WEB-pages have a large number of errors, which are subject to correction and improvement to reach a good level of maturity. This will ensure better results in the service of citizens and employees who work for these institutions.

\section{REFERENCES}

[1] G. Dimitrov, S. Manolov , L. Blagoev and A. Kuyumdzhieva, "State of the E-government in Bulgaria", Analysis, Law and Internet Foundation, Sofia, pp. 34-56, 2006.

[2] E. Castro, "HTML, XHTML \& CSS", Visual Quickstart Guides, Sixth Edition, Peachpit Press, pp. 345-346, 2007.

[3] M. Petrova, "Informatization of public in Bulgaria", pp. 24-47, FABER, Veliko Tarnovo, 2014.

[4] M. Petrova and G. Dimitrov, "E-justice - the guarantee of an effective judicial system. Initiatives in Bulgaria", REVISTA NAȚIONALĂ DE DREPT (Publicaţie periodică ştiinţifico-practică), Universitatea de Stat 
din Moldova, Chisinau, Moldova, nr.10-11 (133-134), pp. 169-173, 2011.

[5] M. Petrova, "Internet-presence and internet-exposure of the courts in Bulgaria", VI International Scientific Conference "Innovations in technology and education", KuzGTU, Belovo, May, 2013, v. 2, pp.159165.

[6] M. Petrova, "Research of web-sites in the district courts of Bulgaria regulatory compliance", VI International Scientific Conference "Innovations in technology and education", KuzGTU, Belovo, May, 2013, v.2, pp. 159-165.

[7] Official Journal of the European Union, C 182, pp 2-13, Volume 57, June, 2014.

[8] "Optimize your Pingdom alerts", PINGDOM tutorial Tools, http://royal.pingdom.com/tag/tutorial/ Retrieved, July, 2015
[9] R. Fishkin and Moz Staff , "The beginer's Guide to SEO", http://d2eeipcrcdle6.cloudfront.net/guides/M-The-Beginners-Guide-ToSEO.pdf, Retrieved, August, 2015.

[10] M. Stefanova, T. Stefanov and O. Asenov, "Access to E-government' Services through Vein-code Biometric Identification", 7th Iberian Conference on Information Systems and Technologies, Madrid, Spain, June 2012, Vol. II, pp.174-176.

[11] Stefanov, T. "Methods for Assessing Information Sites", XLVII International Scientific Conference on Information, Communication and Energy Systems and Technologies ICEST'12, Bulgaria, Veliko Tarnovo, June 2012, Vol.2, pp. 455 - 458.

[12] Web Content Accessibility Guidelines (WCAG) Overview. World Wide Web Consortium, Retrieved, April, 2009. 